\title{
E-government Implementation in Kenya, an evaluation of Factors hindering or promoting e-government successful implementation
}

\author{
Francis Osanya Wamoto \\ ICT officer \\ The Judiciary \\ Republic of Kenya
}

\begin{abstract}
Use of ICT in Government has ability to improve service delivery to its citizens, and yet many developing countries have lagged behind in the implementation of E-government. Many e-government initiatives also failed to achieve their objectives in developing countries. This paper therefore aims to identify critical failure or success factors in Kenya, using Heeks' Factor Model. A survey questionnaire was developed and data were collected and analyzed from officials and interested citizens. The analysis result enabled to highlight seven specific success and failure factors in Kenya. The enablers of e-government projects are good strategy formulation, internal and external drive, employee competence and enough funding, whereas main failure of e-government are weak ICT infrastructure, poor Project management and Design. Data analysis highlights both strengths and weaknesses for each factor or factor. Finally, the study ends up with recommendations for policy makers to shape the future of e-government system in developing countries.
\end{abstract}

Keywords: E-government implementation, Success and failure factors, Kenya.

\section{INTRODUCTION}

Todays, e-government is well known to improve public service delivery. Its adoption results in greater efficiency and effectiveness of government administration. Therefore, egovernment emerged as a hot issue in the academic circles and among policy makers from both the developing and industrialized nations [1]. In particular, the implementation of e-government initiatives has become one of the main goals in several countries including countries in the East Africa, more specifically the Republic of Kenya.

The Kenyan Government approved E-Government strategy in 2004, making the start of e-government journey. In 2006, National ICT policy was approved under the Ministry of Information and Communications (MoICT). The government has since initiated several e-government systems with the aim of enhancing efficiency, transparency and democracy within public administration. Some examples are e-Registry for business registration, passport application and processing system, and G-pay. "The overall goal of e-government is to make the Government more result oriented, efficient and citizen centered" [2].

However, e-government implementation is not a simple task. E-government initiatives have encountered different problems in its implementation and thus these have not been fully implemented in developing countries. The success or failure of e-government programs does not rely on whether they are implemented in developed or developing countries. Developing countries tend to have experienced more failures than advanced ones in implementing e-government [3]. Therefore, a thorough analysis on these problems is required to identify the challenges in developing countries.

This paper therefore aims to investigate critical failure or success factors that influence implementation of egovernment systems in Kenya, using Heeks' Factor Model. A survey questionnaire was developed and data were collected and analyzed from officials and interested citizens. Data analysis highlights both strengths and weaknesses for each factor or variable. Finally, the study ends up with recommendations for policy makers to shape the future of egovernment system in developing countries.

\section{ICT ENVIRONMENT}

\section{SURROUNDING E-GOVERNMENT IN KENYA}

After the adoption of the Vision 2030 roadmap, Kenya has largely experienced dynamism in the telecommunication sector hence national development plans have sought to take advantage in exploitation of its potential by promoting business process outsourcing (PBO) and IT-enabled services (ITES). Figure 1 illustrates the growth of mobile and internet penetration in Kenya since 1999 until 2012.

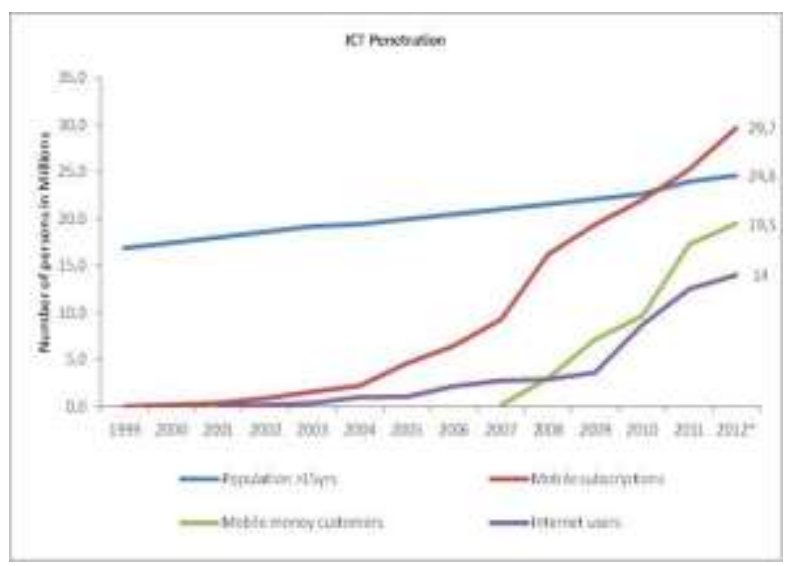

Figure 1. ICT penetration (Source: Julisha report (Kenya) 
The liberalization of the telecommunications market started in the year 1999; this would then give a wide scope for the private sector innovation and market entry. At around the same period, the Communication Commission of Kenya (CCK) was established with a mandate of regulating the sector hence issued for the first time ISPs with licenses. Monopoly was experienced where Telkom Kenya Ltd operated the internet gateway and backbone until 2004. The national backbone was expanded during this period, however the international bandwidth never increased until the end of Telkom's exclusivity period.

The first e-Government strategy was formulated in 2004 and was approved in December, 2004. This was to create order and harmony in Government ICT initiatives which were at the time invariably characterized by disharmony and lack of coordination with each department pursuing their own ICT agenda which resulted to wastage through duplication of resources. Therefore, the key strategy was to set up ICT institutions that would immediately address this. Directorate of e-Government was to oversee, among others mandates, coordination of implementation of strategy, formulation and communication of ICT guidelines and enforcement of national and international standards (roles being played by ICT Authority after merging E-government Directorate, GITS and ICT Board)

The following are some of the projects that were implemented during the five year plan. Key among them is the Integrated Financial Management Information System (IFMIS) and Integrated Personnel and Payroll Database (IPPD) which are fully operational in the ministries. Other applications that have been rolled out include the Local Authorities Integrated Financial Operations Management Systems (LAIFOMS), Education Management Information System (EMIS), Integrated Taxation Management Systems (ITMS) currently known as ITAX after making great improvement in design, online Recruitment and Selection System in the public service commission and the Border control System in the Ministry of state for Immigration and Registration of persons.

The current state of Kenya e-Government system is for general administration including personnel, finance, procurement system, budget, email system among others. They are constructed as main online systems the public service provides for daily life to its citizens. Most systems run in individual departments for instance the national tax system, immigration information system, legal information system and education system. However, information exchange in these department is manual. The National ID, Passport tracking service, Examination result and candidate selection system and public tender system are also provided in the form of e-service though are limited as partial service [4].

\section{SUCCESS OR FAILURE FACTORS OF E-GOVERNMENT IN KENYA}

According to [2], e-Government is defined as "the use of ICT such as the wide area network, internet, and mobile computing, by government agencies to transform government operations in order to improve effectiveness, efficiency, service delivery and to promote democracy." Similarly, [5] defines e-government as the use of ICTs to improve public services delivery, and it brings with the promise of greater efficiency and effectiveness in the public sector."
Many studies have been carried out in order to identify critical success factors (CSFs) that influence e-government initiative implementation. [6]Identified $13 \mathrm{CSFs}$ that are associated with e-government implementation. On the other hand, [7] formulated 27 CSFs just to mention a few. Ultimately, such success or failure factors that many researchers have suggested are well summarized into a Factor Model (FM) developed by [8] as an assessment framework for egovernment in developing countries.

The FM highlights failure, success and improvisations areas as well as gap between design realities. It particularly expands the objectives and values dimension into elements on the drivers, strategy and change management [9]. The FM model comprises Drivers (external and internal pressure), Enablers (Strategy, management, design, competences, technology and others), and Constraints (considered as the negative aspects of drivers and enablers) as explained in Figure 2. This study chose the FM model because it focuses on human factor known to be critical to e-government projects successes and failures [10]. The FM model enables to identify and prioritize a list of e-government projects' success and failure factors based on perception of stakeholders in Kenya. This model summarizes the reasons behind success and failure of egovernment projects. Left-pointing items encourage failure; right-pointing items encourage success.

EGOVERNMENT
FAILURE

Figure 2. A factor model for e-government success and failure

This study therefore used Hicks' Factor Model to identify critical success factors (CSFs) that influence e-government initiative implementation in Kenya. First of all, iinternal and external drive for e-government is very important for successful implementation. External pressure relates to support for reform and achievement of e-government projects' goal from outside government such as aid donors, civil society and citizen, whereas internal pressure is associated with support from key internal government officials for reform and achievement of e-government projects' goals [8]. In order to achieve a successful project in civil agencies it has to be endorsed by top management [11]. Strong support from top officials is required throughout the implementation process in order to avoid e-government implementation facing obstacles such as resistance to change. Pressure from citizens for quicker services from government is also a good drive that can improve e-government implementation. There is a significant pressure from citizens in the Kenyan environment for faster services from government to citizens hence 
pressurizing the government to improve service delivery by adopting and implementing e-government services. In the Kenyan context internal drive is highly indicating that there is a good political will towards e-government implementations. Another important factor for e-government implementation is strategy, and success in providing public services online highly depends on the strategy undertaken or adopted. Strategy relates to availability of overall vision and master plan for good governance and for e-government projects' implementation [8]. Kenya has taken a leading role in egovernment implementation as compared to her other sister countries in East Africa. She has an approved ICT Master plan and an e-government strategic plan which is a roadmap to guide improvements to the online service to her people. Strategy works hand in hand with vision and therefore egovernment implementation begins with establishing a broad vision hence forming a goal of any organization.

Management is related to three factors such as project management to deal with clear roles and planning, change management as incentives to create commitment, and change agents for projects. [12] Argues that change management in egovernment implementation is a very complex issue. However, change management has not been enough considered because e-government is predominantly seen only as a technology mission, not organizational transformation issue. Changes expected are mostly caused by policies and legislation, public-private partnership and finally a huge resistance to change. Change management is a structured approach to transitioning individuals, teams and organizations from the current state to the desired future state [12].

Another much overlooked factor is design. Design relates to the availability of effective modular and incremental approach. Design requires stakeholders to participate at or involve in the inception of projects. Many e-government projects have failed to meet the needs of the users because stakeholders' involvement is overlooked in design development. In the Kenyan case, there might be more underlying factors that caused the election system to fail.

An innovation with substantial complexity requires more technical skills and needs greater implementation and operation efforts to increase their chances of adoption. [11] Insist that e-government adoption need a number of technical staff to help implement it. Many governments have suffered from lack of technical staff and are therefore very important component of factor in e-government implementation. In similar, competency factor was considerably weak and therefore classified as a constraint in e-government implementation in Kenya.

Infrastructure is a backbone of any e-government implementation initiative in both developed and developing countries. In many developing countries, infrastructure appears to be the main challenge why their e-government projects fail. The same scenario is not exceptional for Kenya. Infrastructure that is capable of supporting and enabling the execution of e-government is a requirement for successful egovernment implementation [11]. An e-government infrastructure includes an infrastructure application server environment and its security, data and content management tools, application development tools, hardware and operating system, and systems management platform [11].

Last, funding is a critical factor for both starting e-government initiatives and continuing their implementation. Therefore, the importance of funding in providing excellent service cannot be over emphasized. It is the glue that holds the building, collections and staff together and allows attaining goals [13]. They further insist that funding is essential in providing excellent service to citizens through excellent service delivery mechanisms.

\section{DEVELOPMENT OF STAKEHOLDER'S PERCEPTION QUESTIONNAIRE}

The questionnaire was prepared after a detailed study had been made of the previous literature and ICT environment in Kenya. The first part of the study focused on collecting the relevant documentation so that a more comprehensive picture of e-government system in Kenya could be determined in order to prepare survey questionnaires.

The possibility of surveying practices of e-government implementation by applying a limited number of questionnaires to the Ministry of ICT, ICT Authority, the IEBC and the Judiciary was therefore examined. This received good positive responses from many government officers and citizens. The survey was considered timely and valuable because Kenya had implemented e-government system since 2004 and no such study had been performed. To accomplish this, critical success and failure factors were constructed together with their relevant elements to measure the stakeholder's perception of e-government in Kenya.

Seven factors with a total of 33 variables were selected from the literature survey. Twenty three of these were based on Heeks' model (2003) which included drive, strategy, management, design, competencies, infrastructure, and other resources. The remainder were added to and deleted from each factor by reviewing a wider range of literature as well as Kenyan e-government system.

Based on this background, the questionnaire was constructed. The wording was intentionally directed towards all government officers and citizens who would respond to it. Following the pilot study the questionnaire was amended and some wording was changed. The final questionnaire was divided into two parts and the ratio scaling approach used. Part I concentrated on questions which would identify or categorize respondents; they included their organization, position/title, gender, etc. Anonymity was preserved. Part II was originally designed to measure 33 elements divided into seven critical factors of e-government systems using an interval response scale. Five point Likert scale questions were used and respondents were supposed to rate their responses. Stakeholders were able to indicate their perception of how well the e-government systems were run in the government (1 $=$ Strongly Disagree, $2=$ Disagree, $3=$ Neutral, $4=$ Agree, $5=$ Strongly Agree). This means that 1 represents weakness with 3 being moderate and 5 being strength. Therefore, a score of 3 was regarded as the neutrality point to differentiate the success or failure factor. Finally, the stakeholder's overall perception of benefits from e-government implementation was sought.

\section{STATISTICAL ANALYSIS OF RESULTS SURVEYED}

The purpose of data collection was to test and assess the success and failure factors of e-government application implementation in Kenya. The Ministry of ICT, ICT 
Authority, the IEBC and the Judiciary have a good number of ICT employees totaling to approximately 2000. The population of interest in this study comprised of the staff based in Nairobi and other major towns e.g. Mombasa, Kisumu Eldoret and Nakuru to represent the urban setting while the rest of the towns in Kenya to represent the rural setting. This study focused on the Government to Citizen Domain and therefore chose a small sample from the ordinary Citizens from five major towns of Nairobi, Mombasa, Kisumu Nakuru, and Eldoret (Urban-setting) and other towns as rural setting who were interested in e-government adoption. From these samples of the stated towns the study chose randomly thirty respondents from the general public. The data gathered was obtained using structured closed ended questionnaires for a period of three months, from 24th March to 21st June, 2015. The authors distributed 350 questionnaires to the ICT officers and other staff members in the Judiciary, the Ministry of ICT, the IEBC and ICT Authority, Kenya Revenue Authority, Ministry department Agencies and to the general public. 326 responses were received, however 17 responses were disqualified for various reasons such as lack of knowledge of any existing e-Government applications. The remaining 308 responses ( $88 \%$ of total) were accepted as valid. According to [14], a response rate of $50 \%$ or more is ideal for data analysis. Table 1 provides a general overview of the Kenya officials who participated in this study in terms of demographic information including gender, age bracket, position they hold and their town of residence.

Table 1. Demographic Information of Respondents

\begin{tabular}{cccc}
\hline \multicolumn{4}{c}{ Demographic Information of Respondents } \\
\hline & Variable & Frequency & $\%$ \\
\hline \multirow{3}{*}{ Gender } & Female & 124 & 40.3 \\
& Male & 184 & 59.7 \\
\hline & $18-24$ & 11 & 3.6 \\
& $25-34$ & 140 & 45.5 \\
& $35-44$ & 107 & 34.7 \\
Age & $45-54$ & 48 & 15.6 \\
& $55-64$ & 2 & 0.6 \\
\hline & ICT Head & 37 & 12 \\
& ICT Staff & 177 & 57.5 \\
& Project & & \\
Position & Manager & 82 & 26.6 \\
& & & \\
& Other Positions & 12 & 3.9 \\
\hline & Nairobi & 188 & 61 \\
& Mombasa & 10 & 3.2 \\
& Kisumu & 13 & 4.2 \\
& Naluru & 14 & 4.5 \\
& Eldoret & 32 & 10.4 \\
Town of Residence & Other Towns & 51 & 16.6 \\
\hline
\end{tabular}

\section{RELIABILITY AND VALIDITY \\ VERIFICATION}

The reliability of an instrument refers to the degree to which the instrument is free of random error. It is concerned primarily with consistency and stability of the measurement. Internal consistency tends to be a frequently used type of reliability in the IS domain [15]. Validity is often defined as the extent to which an instrument measures what it purports to measure and validity requires that an instrument is reliable, but an instrument can be reliable without being valid [16]. In this study Cronbach's coefficient alphas calculated based on the average item to item correlations was used to measure internal consistency. The results are presented as shown below in table 2. The values of the study instrument are reliable. The acceptable Cronbach's alpha value range from 0.7 to 0.95 and that means the cut-off point is at 0.7. [17] Says values below 0.7 can realistically, be expected because of the diversity of constructs being measured.
Table 2. Cronbach's Alpha Reliability

\begin{tabular}{|c|c|c|c|c|}
\hline Factor & $\begin{array}{l}\text { No. of } \\
\text { Ttems }\end{array}$ & $\begin{array}{l}\text { Cronbach's } \\
\text { Alohh }\end{array}$ & Mean & $\begin{array}{l}\text { Oterall } \\
\text { Rating }\end{array}$ \\
\hline Drive & 4 & 0.716 & 4.0048 & 7.1 \\
\hline Strategy & 4 & 0.745 & 3.885 & 7.2 \\
\hline Management & 4 & 0.813 & 3.517 & 6.5 \\
\hline Design & 5 & 0.765 & 3.431 & 6 \\
\hline Competencies & 4 & 0.69 & 3.364 & 5.8 \\
\hline $\begin{array}{l}\text { Infrastructure } \\
\text { Other Resources }\end{array}$ & 5 & 0.756 & 2.647 & 4.6 \\
\hline (Funding) & 3 & 0.685 & 3.065 & 5.4 \\
\hline
\end{tabular}

In order to verify whether all questions used in the questionnaire for measuring variables in the research model were suitable as measuring tools, the researcher carried out a factor analysis by AMOS. Confirmatory Factor Analysis by AMOS standard values are recommended that GFI, NFI and TLI be higher than 0.9. AGFI value to be more than 0.8 and RMR be lower than 0.05 [18]. The instrument used in this study met almost the required criteria required a part from Infrastructure factor. The result of this analysis is as shown in the Table 3 below

Table 3. Confirmatory Factor Analysis

\begin{tabular}{|c|c|c|c|c|c|c|c|c|c|}
\hline Construct & $\begin{array}{l}\text { Intial } \\
\text { itters }\end{array}$ & $\begin{array}{l}\text { Find } \\
\text { items }\end{array}$ & GF & AGFI & RNR & NF & $r$ & P-ablue & $Q$ \\
\hline DA & 4 & 4 & 0978 & 0.389 & 0069 & 0960 & 13.783 & 0001 & 6891 \\
\hline$\$ A$ & 4 & 4 & 0.985 & 0.926 & 0,000 & 0.968 & 8880 & 0.012 & 4.40 \\
\hline MA & 6 & 4 & 0.994 & 0970 & 0.017 & 0.991 & 3.602 & 0.162 & 1.821 \\
\hline DA & 5 & 4 & 0978 & 0.289 & 0059 & 0960 & 13.733 & 0.001 & 5.891 \\
\hline$C A$ & 4 & 4 & 0967 & 0.335 & 00075 & 0.902 & 21.657 & 0.000 & 10.829 \\
\hline IA & 5 & 3 & 1000 & - & 0.000 & 1000 & - & - & - \\
\hline Os & 4 & 4 & 0,994 & 0.971 & 0.037 & 0996 & 3512 & 0.173 & 1.756 \\
\hline
\end{tabular}

\subsection{Convergent Validity}

Convergent validity is a function of the association between two different measurement scales which are supposed to measure the same concept, and is achieved when multiple indicators operate in a consistent manner [19]. [20], recommended that composite reliability (CR) should be equal to or greater than .60 , and average variance extracted (AVE) should be equal to or greater than .50 [20]. The results of CR and AVE are presented in Table 4 
Table 4. Convergent Reliability

\begin{tabular}{|c|c|c|c|c|}
\hline item & $\begin{array}{l}\text { Standardized } \\
\text { estimate }\end{array}$ & S.E. & AVE & $C R$ \\
\hline DR1 & 0.702 & 0.475 & \multirow{3}{*}{0.507} & \multirow{3}{*}{0.837} \\
\hline DR2 & 0.791 & 0.330 & & \\
\hline DR3 & 0.670 & 0.225 & & \\
\hline$\frac{D R 4}{S A 1}$ & $\frac{0.680}{0.590}$ & 0.543 & & \\
\hline $\begin{array}{l}\text { SAI } \\
\text { SA2 }\end{array}$ & 0.670 & $\begin{array}{l}0.652 \\
0.518\end{array}$ & \multirow{3}{*}{0.501} & \multirow{3}{*}{0.790} \\
\hline SA3 & 0.750 & 0.657 & & \\
\hline SA4 & 0.803 & 0.272 & & \\
\hline MA1 & 0.730 & 0.470 & \multirow{4}{*}{0.520} & \multirow{4}{*}{0.814} \\
\hline MA2 & 0.691 & 0.466 & & \\
\hline MA3 & 0.711 & 0.466 & & \\
\hline MA6 & 0.752 & 0.500 & & \\
\hline DA1 & 0.724 & 0.442 & \multirow{3}{*}{0.532} & \multirow{3}{*}{0.808} \\
\hline $\mathrm{DA} 2$ & 0.650 & 0.408 & & \\
\hline $\begin{array}{l}\text { DA3 } \\
\text { DAS }\end{array}$ & $\begin{array}{l}0.797 \\
0.740\end{array}$ & $\begin{array}{l}0.351 \\
0.811\end{array}$ & & \\
\hline CA1 & 0.665 & 1.140 & \multirow{4}{*}{0.506} & \multirow{4}{*}{0.705} \\
\hline CA2 & 0.671 & 0.774 & & \\
\hline CA3 & 0.648 & 0.940 & & \\
\hline$\frac{C A 4}{\text { IA1 }}$ & 0.843 & 0.378 & & \\
\hline IA1 & 0.859 & & \multirow{3}{*}{0.592} & \multirow[b]{2}{*}{0.755} \\
\hline IA2 & 0.922 & 0.196 & & \\
\hline OA1 & $\frac{0.452}{0.841}$ & $\frac{1.020}{0.420}$ & & \multirow{4}{*}{0.709} \\
\hline & & & \multirow{3}{*}{0.502} & \\
\hline$O A 3$ & 0.585 & 1.267 & & \\
\hline OA4 & 0.541 & 1.102 & & \\
\hline
\end{tabular}

\section{DESCRIPTIVE STATISTICAL PERSPECTIVE}

\subsection{Gender of Respondents}

Male respondents were slightly higher $(59.7 \%)$ than the female respondents $(40.3 \%)$ implying a normal ratio distribution in any setting. On a gender grouped T-test, there is a significant difference in Drive and Other (Funding) factors (see Table 5.5). The result revealed that male had high score that female respondents. All other factors showed insignificant levels, which means no difference male and female. The results are as shown in Table 5 below.

Table 5. Grouped T-test on Gender

\begin{tabular}{|c|c|c|c|c|c|c|c|c|}
\hline \multicolumn{2}{|c|}{ GENDER } & Mean & Std. Deviation & $F$ & Sig. & $t$ & $\begin{array}{c}\text { Sig. } \\
\text { (2-tailed) }\end{array}$ & $\begin{array}{c}\text { mean } \\
\text { difference }\end{array}$ \\
\hline \multirow{2}{*}{ DR } & Male & 41835 & .58183 & \multirow{2}{*}{1.148} & \multirow{2}{*}{285} & \multirow{2}{*}{3.252} & \multirow{2}{*}{.001} & \multirow{2}{*}{2269} \\
\hline & Female & 3.9565 & 61305 & & & & & \\
\hline \multirow{2}{*}{ SA } & Male & 3.9758 & .67732 & \multirow{2}{*}{1.595} & \multirow{2}{*}{208} & \multirow{2}{*}{1.852} & \multirow{2}{*}{.065} & \multirow{2}{*}{.1524} \\
\hline & Female & 3.8234 & .72855 & & & & & \\
\hline \multirow{2}{*}{ MA } & Male & 3.6069 & .68534 & \multirow{2}{*}{12.508} & \multirow{2}{*}{.000} & \multirow{2}{*}{1.620} & \multirow{2}{*}{.106} & \multirow{2}{*}{.15033} \\
\hline & Female & 3.4565 & .86651 & & & & & \\
\hline \multirow{2}{*}{$D A$} & Male & 3.4819 & .68534 & \multirow{2}{*}{3.096} & \multirow{2}{*}{.079} & \multirow{2}{*}{.998} & \multirow{2}{*}{319} & \multirow{2}{*}{.08512} \\
\hline & Female & 3.3967 & .76479 & & & & & \\
\hline \multirow{2}{*}{$C A$} & Male & 3.2964 & .91140 & \multirow{2}{*}{2.240} & \multirow{2}{*}{.135} & \multirow{2}{*}{-1.130} & \multirow{2}{*}{259} & \multirow{2}{*}{-11260} \\
\hline & Female & 3.4090 & 81913 & & & & & \\
\hline \multirow{2}{*}{ IA } & Male & 27204 & .97705 & \multirow{2}{*}{.573} & \multirow{2}{*}{.450} & \multirow{2}{*}{1.122} & \multirow{2}{*}{263} & \multirow{2}{*}{.12260} \\
\hline & Female & 2.5978 & 91541 & & & & & \\
\hline (1) & Male & 3.2500 & .65176 & 3065 & 091 & & 00 & \\
\hline & Female & 3.0340 & .78354 & 2.000 & 501 & 3.010 & 000 & 3000 \\
\hline
\end{tabular}

\subsection{Position of Respondents}

A majority of the respondents i.e. $177(57.5 \%)$ indicated that they work as ICT staff, followed by $82(26.6 \%)$ who were Project Managers, $37(12 \%)$ ICT Heads, and the least 12 $(3.9 \%)$ were ordinary citizen with interest in e-government implementations in Kenya. The researcher carried a grouped T-test to find out the perception to all the factors between Managers and Operators. Managers included top ranking officials (ICT Heads) in the government whereas operators included ICT staffs and Project Managers. The results as shown in Table 6 below are significant more especially in
Drive, Strategy, Design, Competence and Infrastructure factors. Operator group were higher than managers in five factors, meaning that manager group have lower perception of these factors being driving force for successful implementation of e-government in Kenya. On the other hand, both management and funding factors showed no difference between operator and managers.

Table 6. Grouped T-Test on Position

\begin{tabular}{|c|c|c|c|c|c|c|c|c|}
\hline \multicolumn{2}{|c|}{ Position } & Mean & Std. Deviation & $F$ & Sig. & $t$ & $\begin{array}{c}\text { Sig. } \\
\text { (2-tailed) }\end{array}$ & $\begin{array}{c}\text { mean } \\
\text { difference }\end{array}$ \\
\hline \multirow{2}{*}{$D R$} & Manager & 4.0116 & .62712 & \multirow{2}{*}{2.588} & \multirow{2}{*}{.109} & \multirow{2}{*}{-2.420} & \multirow{2}{*}{.016} & \multirow{2}{*}{ 6- -22821} \\
\hline & Operator & 4.2398 & .47037 & & & & & \\
\hline \multirow{2}{*}{ SA } & Manager & 3.8359 & .72811 & \multirow{2}{*}{3.158} & \multirow{2}{*}{.077} & \multirow{2}{*}{-2.801} & \multirow{2}{*}{.005} & \multirow{2}{*}{-30695} \\
\hline & Operator & 4.1429 & 55199 & & & & & \\
\hline \multirow{2}{*}{ MA } & Manager & 3.5010 & .79743 & \multirow{2}{*}{.726} & \multirow{2}{*}{.0395} & \multirow{2}{*}{-0.810} & \multirow{2}{*}{.419} & \multirow{2}{*}{-10108} \\
\hline & Operator & 3.6020 & .82114 & & & & & \\
\hline \multirow{2}{*}{$D A$} & Manager & 3.3890 & .73300 & \multirow{2}{*}{.051} & \multirow{2}{*}{821} & \multirow{2}{*}{-2.326} & \multirow{2}{*}{.021} & \multirow{2}{*}{-26407} \\
\hline & Operator & 3.6531 & .70492 & & & & & \\
\hline \multirow{2}{*}{$C A$} & Manager & 3.3127 & .86612 & \multirow{2}{*}{1.682} & \multirow{2}{*}{.196} & \multirow{2}{*}{-2.413} & \multirow{2}{*}{.016} & \multirow{2}{*}{-31991} \\
\hline & Operator & 3.6327 & .76564 & & & & & \\
\hline \multirow{2}{*}{ IA } & Manager & 2.5714 & .92269 & \multirow{2}{*}{.010} & \multirow{2}{*}{919} & \multirow{2}{*}{-3.300} & \multirow{2}{*}{.001} & \multirow{2}{*}{-47619} \\
\hline & Operator & 3.0476 & .94526 & & & & & \\
\hline 0 & Manager & 3.0299 & .72958 & & 078 & 1031 & 051 & \\
\hline A & Operator & 3.2500 & .74302 & (.001 & $9 / 14$ & -1.951 & .034 & $-2 \angle 000$ \\
\hline
\end{tabular}

\subsection{Residence of Respondents}

A majority of the respondents $188(61 \%)$ reside in Nairobi, 32 $(10.4 \%)$ reside in Eldoret, $14(4.5 \%)$ in Nakuru, $13(4.2 \%)$ in Kisumu, $10(3.2 \%)$ in Mombasa and the rest $51(16.6 \%)$ reside in other towns across the country. This shows that the survey was a representative of the entire country covering both urban and rural settings. On grouped T-test, there was significant difference between Cities (Nairobi, Mombasa, and Kisumu) and other towns (Nakuru, Eldoret and other small towns) in Design Assessment. Other factors did not post significant results. Respondents living in cities have high perception of Design factor as a success factor in implementing e-government than respondents living in other towns.

Table 7. Grouped T-test on Respondents residence

\begin{tabular}{|c|c|c|c|c|c|c|c|c|c|c|}
\hline & & $\mathrm{N}$ & Mean & $\begin{array}{c}\text { Std } \\
\text { Deviation }\end{array}$ & $\begin{array}{l}\text { Std. } \\
\text { Error } \\
\text { Mean }\end{array}$ & $F$ & Sig. & & $\begin{array}{l}\text { Sig. } \\
\text { (2- } \\
\text { tailed) }\end{array}$ & $\begin{array}{l}\text { Mean } \\
\text { Difference }\end{array}$ \\
\hline \multirow[t]{2}{*}{ DR } & $\begin{array}{l}\text { other } \\
\text { towns }\end{array}$ & 97 & 4.1134 & .40023 & .04064 & 11.274 & .001 & 1.279 & 202 & .09563 \\
\hline & cities & 211 & 4.0178 & 68399 & .04709 & & & & & \\
\hline \multirow[t]{2}{*}{ SA } & $\begin{array}{l}\text { other } \\
\text { towns }\end{array}$ & 97 & 3.8119 & .62503 & .06346 & 3.167 & .076 & 1.220 & 223 & -.10639 \\
\hline & cities & 211 & 3.9182 & .74651 & .05139 & & & & & \\
\hline \multirow[t]{2}{*}{ MA } & $\begin{array}{l}\text { other } \\
\text { towns }\end{array}$ & 97 & 3.6366 & .69599 & .07067 & 5.029 & .026 & 1.783 & .076 & .17451 \\
\hline & cities & 211 & 3.4621 & .84041 & .05786 & & & & & \\
\hline \multirow[t]{2}{*}{$D A$} & $\begin{array}{l}\text { other } \\
\text { fowns }\end{array}$ & 97 & 3.6108 & .67118 & .06815 & 1.958 & .163 & 2.952 & .003 & 26248 \\
\hline & cities & 211 & 3.3483 & .74808 & .05150 & & & & & \\
\hline \multirow[t]{2}{*}{ CA } & $\begin{array}{l}\text { other } \\
\text { towns }\end{array}$ & 97 & 3.3840 & .85396 & .08671 & .261 & .609 & .282 & .778 & .02976 \\
\hline & cities & 211 & 3.3543 & .86143 & . 05930 & & & & & \\
\hline \multirow[t]{2}{*}{ IA } & $\begin{array}{l}\text { other } \\
\text { towns }\end{array}$ & 97 & 2.6976 & .95268 & .09673 & .004 & .950 & .637 & .525 & .07358 \\
\hline & cities & 211 & 2.6240 & .93705 & .06451 & & & & & \\
\hline \multirow[t]{2}{*}{$O A$} & $\begin{array}{l}\text { other } \\
\text { towns }\end{array}$ & 97 & 3.1443 & .66618 & .06764 & 2.481 & .116 & 1.287 & .199 & .11589 \\
\hline & cities & 211 & 3.0284 & .76323 & .05254 & & & & & \\
\hline
\end{tabular}




\subsection{Age of Respondents}

More so, a bigger number of the respondents, 140 (45.5\%) were aged between 25 yrs. and 34 yrs., followed by 107 (34.7\%) respondents aged between 35 yrs. and 44 yrs., the 48 (15.6\%) respondents between 45 yrs. and 54 yrs., then 11 (3.6\%) of respondents were between 18 yrs. and 24 yrs. and the least were $2(0.1 \%)$ respondents who were aged between 55 yrs. and 64 yrs. The youths (age 18-44 years) have high perception about Strategy factor in enabling successful implementation of e-government than the old (45 years and above). There was a significant difference in Strategy factor as shown in figure 8 below.

Table 8. Grouped T-test on Age

\begin{tabular}{|c|c|c|c|c|c|c|c|c|c|}
\hline & & $\mathrm{N}$ & Mean & $\begin{array}{c}\text { Sid } \\
\text { Deviation }\end{array}$ & $F$ & Sig. & 1 & $\begin{array}{l}\text { Sig (2. } \\
\text { tailed) }\end{array}$ & $\begin{array}{l}\text { Mean } \\
\text { Difference }\end{array}$ \\
\hline \multirow[t]{2}{*}{$\overline{D R}$} & old & 50 & 40300 & 63011 & 257 & 612 & .226 & 821 & .02136 \\
\hline & young & 258 & 4.0514 & 60721 & & & & & \\
\hline \multirow[t]{2}{*}{ SA } & old & 50 & 40950 & 71409 & 064 & 801 & 2300 & 022 & 25101 \\
\hline & young & 258 & 3.8440 & .70479 & & & & & \\
\hline \multirow[t]{2}{*}{$\overline{M A}$} & old & 50 & 36000 & 95164 & 7,575 & .006 & 800 & .424 & .09903 \\
\hline & young & 258 & 3.5010 & 76921 & & & & & \\
\hline \multirow[t]{2}{*}{$D A$} & old & 50 & 3.4200 & 91116 & 11.938 & 001 & .116 & 908 & .01314 \\
\hline & young & 258 & 3.4331 & 69646 & & & & & \\
\hline \multirow[t]{2}{*}{$\overline{C A}$} & old & 50 & 3.1950 & 98624 & 1.302 & 255 & .1522 & .129 & -20132 \\
\hline & young & 258 & 3.3963 & .82881 & & & & & \\
\hline \multirow[t]{2}{*}{$\mathbb{A}$} & old & 50 & 2.6333 & 1.05032 & 1025 & 312 & .114 & 910 & .01654 \\
\hline & young & 258 & 2.6499 & 92062 & & & & & \\
\hline \multirow[t]{2}{*}{$\overline{O A}$} & old & 50 & 30000 & 94761 & 12.257 & 001 & .682 & 496 & .07752 \\
\hline & young & 258 & 3.0775 & 68779 & & & & & \\
\hline
\end{tabular}

\section{CURRENT STATUS OF E- GOVERNMENT SYSTEM IMPLEMENTATION}

With regard to the status of e-government implementation, 194 (63\% of total) respondents indicated that the egovernment systems have been successfully implemented and $101(32.8 \%$ of total) currently implemented. Meanwhile, 7 ( $2.3 \%$ of total) indicated that they are in the planning stage, whereas only $6(1.9 \%)$ being failed.

IFMIS is widely known by the respondents $(45.5 \%$ of total) with ITAX $16.2 \%$. This means that IFMIS system is widely implemented across the government Offices and that is the most successfully implemented E-application in Kenya. The biggest responsibility for implementing the e-government lies in government $(65.6 \%$ of total) with the second in public private partnership (26\% of total). Minimal portion of responsibility ( $8.4 \%$ of total) is accounted for by International Development Agencies (Donors) and private agencies and the rest.

On the other hand, the findings illustrated in Table 4 reveals that $95.5 \%$ of the respondents strongly understand the benefits of e-government to citizens, whereas only $4.5 \%$ of the respondents disagree with the majority's view. The overwhelming support of e-government at $97.4 \%$ is a strong indication that Kenyans have embraced e-government, which will be a push factor for successful e-government implementation by the Government.
Table 9. Support for E-government Implementation

\begin{tabular}{l|l|c|c}
\hline \multicolumn{4}{c}{ Support for E-gorernment Implementations in Kenya } \\
\hline & Variable & Frequency & $\%$ \\
\hline \multirow{3}{*}{ Individual Support } & Support & 300 & 97.4 \\
\cline { 2 - 5 } & Don' Support & 8 & 2.6 \\
\hline \multirow{3}{*}{$\begin{array}{l}\text { Understanding benefits of E-gort to } \\
\text { Citizens }\end{array}$} & High Benefits & 294 & 95.5 \\
\cline { 2 - 5 } & Low Benefits & 14 & 4.5 \\
\hline
\end{tabular}

\section{ENABLERS AND CONSTRAINTS FACTORS IN E-GOVERNMENT IMPLEMENTATION}

The stakeholder's overall perception was determined by combining all the constituent variables. This produced an average score of 6.086 as the overall perception of egovernment implementation in Kenya. The illustrated graph in figure 4 highlights the observation based on the results of grouped responses of the level of e-government implementation strategy, showing areas of strength and weaknesses calculated by assigning one to strongly disagree (weakness, e-government failure) and ten to strongly agree. Having discussed this with several numbers of global ICT experts, the authors developed a model of evaluating the level of e-Government implementation. It was felt that a mean score above 6.0 was desirable, one below 4.7 indicated immediate corrective action to be implemented and that between 4.7 and 6.0 required gradual action for improvement of e-government implementation. In other words, the model includes the Zone of Constraint (less than 4.7 of total 10; Failure) the Zone of Improvement (between 4.7 and 6.2 of total 10; Partially Success) and the Zone of Enabler (greater than 6.0 of total 10; Success). From this model, The Kenyan e-government implementation belongs to the Zone of Improvement (6.0 of total 10). Figure 4 below illustrates how Zones were classified.

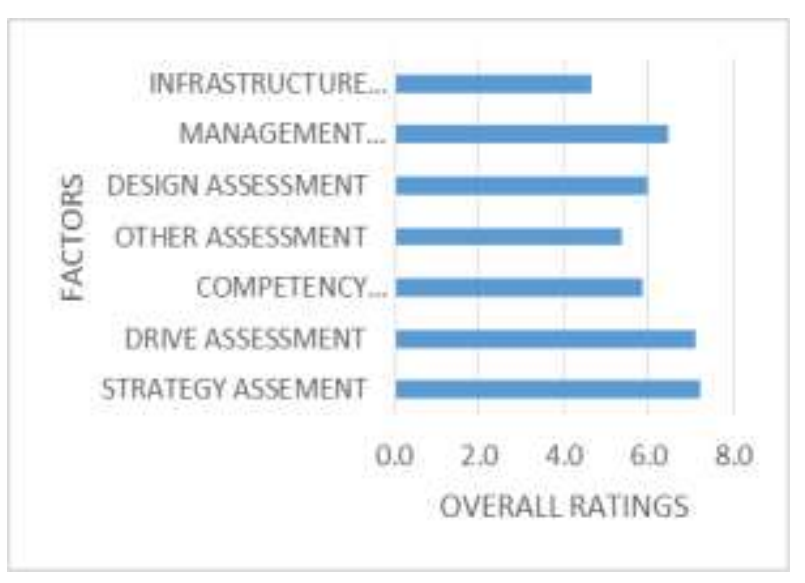

Figure 3. Weighted value of individual factors 


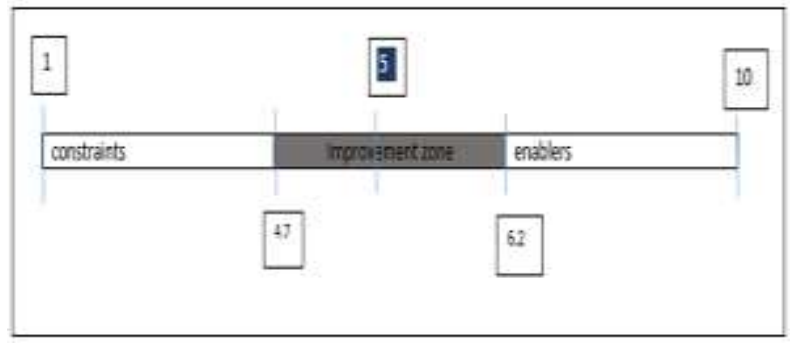

Figure 4. Zone Classification

From the graph in figure 3, the area of weakness is in Infrastructure factor hence form a constraint. On the other hand, Strategy factor presented the strongest score in terms of e-government implementation, followed closely by Drive assessment and Management. They fall under the Zone of Enabler. The remainder Design, Other resources and Competency factor fall under enablers of Improvement. This means that the Kenyan government should focus her efforts to improve Infrastructure and then gradually improve Design, Competency and Other resources factors. In this section the study discusses factor by factor and identifies the weak areas that require improvement for successful implementation of egovernment in Kenya with respect to their weighted score.

With regard to Drive factor in table 5, only three variables were tested and it's shown that all components scored considerably well. It reflects that there is strong drive both from within and outside government for e-government implementations in Kenya. The research also highlights that key government officials recognize e-government issues and have strong drive for their implementation, the two variables scored with almost similar margin. However, this should not be overlooked instead more effort has to be added in order to achieve $100 \%$ implementation.

Strategy factor performed well in this study. All the components score fall under the Zone of Enabler. Existence of National ICT Master plan scored 7.8, followed by Existence of an Approved National ICT policy with 7.4, existence of an e-Government Strategic plan with 7.1 and participation of stakeholders in strategy development with 6.7 score. However, some respondents had reservation about participation of stakeholders in strategy development, which means that more effort for improvement is required in this component.

Six components were tested under management factor; Existence of a Champion organization in Kenya scored considerably high with 7.2 , followed by resistance from workers or employees scored 6.9, perceived infighting among Government departments with 6.5 , Strong consideration of risk in e-government implementation with 6.1 and lastly, Consistence and coordination of e-government projects scored 5.4. This study has identified two underlying components that hinder successful implementation of e-government projects. They are resistance from employees and infighting among government departments. $72.4 \%$ of the respondents concur that there is resistance to change from workers during egovernment projects implementation in Kenya. There existed infighting among Champion organizations i.e. ICT Authority, MoICT and the Treasure due to duplicate mandates among them. As a clear evidence, $62.3 \%$ of respondent agree that there is infighting among Government Departments. The reasons behind this could be due poor project management and lack of clear roles and mandates among government

www.ijcat.com ministries and departments responsible for e-government implementation.

All components in Design factor scored between the Zones of Improvement and Enabler, presence of quick and feasible objectives scored highest of all with 6.7, followed by other components as shown in the table 9. Therefore, more efforts are required to improve design of projects in order to meet the needs of Kenyans as well as achieve the well-intended objectives of e-government applications.

The overall rating of Competence factor was 5.8. Many respondents who were interviewed possessed basic computer skills. However, it seems the government has not taken an initiative to sensitize its employees on e-government.

The infrastructure factor performed poorly and only managed to raise an overall rating of 4.6. The result indicates that there is no adequate Laws on e-transactions, little presence of Security and authentication technology, minimal presence of hardware, software and network technologies as well as minimal interconnections of government offices. A lot of improvement efforts are required for improvement because infrastructure is the bedrock of e-government that cannot be ignored under all circumstances.

Another poorly performed factor is funding of e-government projects. This factor scored an overall rating of 5.4 which falls under the Zone of Improvement. There is an indication that most e-government projects are funded by donors and private sector and this puts the government in a vulnerable position with regard to control of e-government initiatives. This study has therefore recommended among other things, that the government should take charge of e-government initiative as is the wish of many respondents and donors to play an oversight role.

\subsection{Risk Assessment}

All the factor rating score are added up and interpreted according to the table below. In this research, factors scored as follows; Drive Factor 7.1, Strategy Factor 7.2, Management Factor 6.5, Design Factor 6, Competence Factor 5.8, Infrastructure Factor 4.6 and Other Resources (Funding) 5.4. Making an Overall Score of 42.6, thus e-government implementation in Kenya might be a partial failure unless action is taken. As much there seems to be a slight improvement with comparison to the study by [1] where overall performance of e-government in Kenya scored 38.2, the score under this study still falls under the same category of partial failure. See table 10 below. 
Table 10: Risk Assessment layout

\begin{tabular}{cl}
\hline $\begin{array}{c}\text { Overall } \\
\text { rating }\end{array}$ & Likely outcome \\
\hline $0-13$ & $\begin{array}{l}\text { Your e-government project will almost certainly fail } \\
\text { unless action is taken. }\end{array}$ \\
\hline $14-27$ & $\begin{array}{l}\text { Your e-government project may well fail unless action } \\
\text { is taken. }\end{array}$ \\
\hline $28-41$ & $\begin{array}{l}\text { Your e-government might fail totally, or might well be } \\
\text { a partial failure unless action is taken. }\end{array}$ \\
\hline $42-55$ & $\begin{array}{l}\text { Your e-government project might be a partial failure } \\
\text { unless action is taken. }\end{array}$ \\
\hline $56-70$ & Your e-government project may well succeed.
\end{tabular}

\section{DISCUSSIONS AND RECOMMENDATIONS}

E-government was established for the first time in Kenya in 2004 after the adoption of the first ever e-government strategy. So over the last ten years, the government of Kenya initiated major capital investments such as installation of ICT infrastructure. Development partners formed the biggest percentage of funding and the government contributions usually have been in form of technical and support staff and facilities that included buildings. So far the Government Information Technology investment and management framework has connected all Ministries to the internet under the executive Network [21]. The government has also connected all Ministries to run the Integrated Information Systems (IFMIS) and more others.

However, successful implementation of e-government initiatives requires careful planning and other issues that take into consideration a number of factors alongside technology. Many projects have failed because they took a technologycentric approach where technology has been seen as the main drive for e-government development. This study is therefore worthy because it describes the specific success and failure factors and their relevant elements in a particular country for assessing the stakeholder's perception of their e-government system. It is found that good strategy formulation, internal and external drive, employee competence and enough funding are enablers of e-government projects in Kenya as well as in any developing country especially in Africa because the underlying conditions and factors are quite similar.

The study too identified three factors which include poor ICT infrastructure, poor Project management and Design as main failure of e-government in Kenya. This however should not be tied only onto the mentioned seven factors, these were only identified as critical factors for e-government projects implementation in developing countries. Therefore among other things, the findings of this study highlight the need for further research focusing on more factors other than the ones evaluated in this study.

The research found out that among the main factors, Infrastructure scored very low below the minimum to form a constraint in Kenyan e-government implementation process.
Competence and funding (Other Resources) did not do well either. In order to address the constraints and improve on competence and funding factors, this study provides a variety of recommendations. First of all, Kenyan government should create clear role and mandate for champion organization. This study found out that there is significant infighting among government Ministries and departments and this could be due to unclear role definition and duplication, it is therefore important for Kenya to give greater mandate to one organization for instance ICT Authority for implementations of e-government projects as it was before when the Directorate of E-government was in existence.

Second, the Government should develop project planning and management capacities within government, to enable government to give some direction to, and have some control over e-government projects. There needs to be a continuous focus on raising the awareness, understanding and skills of those involved in e-government projects. This must include promotion of the benefits of the projects. In the Kenyan context, the study found out that employees are not well sensitized on e-government which should not be the case because these employees are the super users of e-government system hence they need to be sensitized as early as possible.

Third, the government focus on building telecommunication infrastructure and choose appropriate technology to its environment. This can be based on or building a modern telecommunication infrastructure.

Last, the government should avoid Big Bang approach of project implementation and instead introduce them gradually, systematic way in order to avoid resistance among users of the new technology or application. There should be initial goals and pilot-test the hardware, the database and the new procedures before any attempt to build up to full-scale implementation. E-government projects can be left to drift unless they are well managed. Therefore, e-government projects must include continuous monitoring, and continuous action to improve the project on the basis of that monitoring.

\subsection{Further Recommendations}

- Create clear role and mandate for a champion organization. This study found out that there is significant infighting among government Ministries and departments and this could be due to unclear role definition and duplication, it is therefore important for Kenya to give greater mandate to one organization for instance ICT Authority for implementations of e-government projects as it was before when the Directorate of E-government was in existence.

- Encourage transparency. The government should do whatever can be done to introduce transparency and rationality into procurement and recruitment processes. For example, it may be possible to promote use of a project Web site that gives details of project activities. Involvement of donors may introduce oversight procedures.

- Training/awareness-raising. There needs to be a continuous focus on raising the awareness, understanding and skills of those involved in egovernment projects. This must include promotion of the benefits of the projects. In the Kenyan context, the study found out that employees are not 
well sensitized on e-government which should not be the case because these employees are the super users of e-government system hence need to be sensitized as early as possible.

- Dealing with politics. Some way must be found to deal with the politics, sentiment and self-interest that inevitably forms part of e-government projects. The study therefore recommend that the president should take leadership and create a committee of experts who will directly report to him without any political interference.

- Find political will. The success or failure of egovernment projects - especially those involving citizens and the democratic process - is significantly determined by the political context. Unless there is a political will to see the e-government project succeed, then it is likely to fail.

- Involve civil society. In projects that touch the broader issues of governance, the participation of civil society organizations should be encouraged from the inception. They can have longer-term objectives for improvement of the governance process that can usefully balance objectives in government that may be merely for short-term survival.

- Establish partnerships. Particularly with others who have undertaken similar initiatives.

- Customize e-government goals to current realities. Understanding the motivations and interests of key stakeholders will help designers of e-government systems fit with what is possible, rather than trying to design something that will not happen.

- Customize timescales to current realities. Ministers should not expect automatic and overnight transition to electronic networking. They must recognize that time and groundwork are needed.

- Customize training to user needs. Customize training content to the specific job needs of staff. This may well mean some initial study of work content to understand the role of information and communication (and, hence, the potential role of ICTs) in the work of government staff. In this case,

- Get citizen representation. Apart from experts and government officials, it is desirable to involve the representatives of different categories of citizens in project monitoring and implementation. They can be associated with high-level decision making and review committees.

- Focus on affordable, feasible solutions. The information needs of the institutions involved should be thoroughly assessed. During this process it is in most cases obvious that there is a big difference between those things which are truly necessary and those which people want having seen somewhere else, especially on the Internet. Solutions based on the latter may not be affordable on the long run. Sustainability of e-government initiatives that begun with the help of foreign donors depends in the future on costs which the institution will have to pay out of its own budget. Sustainability will only be achieved by focusing on true and affordable needs, not on 'bells and whistles'.

- Train users early via prototypes. Early training efforts using rapidly-prototyped versions can make weaknesses of the system obvious at a stage where changes and modifications take less time than after making a system final and then handing it over to end users.

- Focus on immediate benefits and high visibility with broad citizen benefit. For an e-government project to succeed, the underlying technology need not be very sophisticated. What is required is an understanding of citizen needs, proper structuring of the project and early delivery of benefits. It is also important to have projects that have a fairly high degree of public visibility and which serve a broad spectrum of society so that people at large are convinced about the use of ICTs in government.

\section{CONCLUSION}

This study has shown that good strategy formulation, internal and external drive and Management are enablers of egovernment projects implementation in Kenya as well as in any developing country especially in Africa because the underlying conditions and factors are quite similar. The study too identified four factors which include poor ICT infrastructure, poor funding, Poor Computer Skills (Competence) and Design as main failure causes of egovernment in Kenya. This however should not be tied only onto the mentioned seven factors, these were only identified as critical factors for e-government projects implementation in developing countries. Therefore among other things, the findings of this study highlights the need for further research focusing on more factors other than the ones evaluated in this study. This study indicated a partial failure of e-government implementation and which require an urgent addressing of the underlying failure factors.

The outcome of this study can provide a big implication on the policy of any developing countries. It is felt that the government must take a clear and leading role in promoting egovernment initiatives for success to be seen. The study has therefore provided several specific recommendations for Governments and policy makers in order to reduce the risk of failure of e-government projects. The reason being, developing countries may have similar characteristics to the Kenyan context which presents various challenges that affect the successful implementation of e-government. The reason is that developing countries may have similar characteristics to the Kenyan context which presents various challenges that affect the successful implementation of e-government.

\section{REFERENCES:}

[1] N. Y. Awiti, 2012. [Online]. Available: http://library.kaist.ac.kr/thesis02/2012/2012M020104524_S1 Ver2.pdf.

[2] GoK-EGS, e-Government Strategy 2004, Government press, 2004. 
[3] I. Syamsuddin, "Evaluation of e-government initiatives in developing countries: An ITPOSMO approach," International Research Journal of Applied and Basic Science, 2011.

[4] GoK, Feasibility Study Report of Kenya Government Integrated Data Center, 2014.

[5] R. Heeks, "Most e-Government for development projects fail: How can risks be reduced?" IDPM i-government working paper, 2003.

[6] T. Altameen, M. Zairi and S. Alshawi, "Critical Success factors of e-government: A proposed model for e-government implementation," 2006.

[7] J. Fortune and D. White, "Framing of projects critical success factors by a system mode," International Journal for project management, 2006.

[8] R. Heeks, "e-government for development: Causes of egovernment success and failure: Factor Model," IDPM, 2003a.

[9] B. Spriano, "Success and failure of e-government projects in developing countries: The case of Zambia," 2013.

[10] R. Heeks, "e-Government for development: Causes of egovernment success and failure: Factor Model," IDPM, 2003.

[11] A. Torki, Z. Mohamed and A. Sarmad, "Critical Success Factors of E-government: A Proposed Model for Egovernment Implementation," IEEEXplore, 2006.

[12] N. Janja, "Change management as a critical success factor in e-government implementation," Journal of Business Systems Research, vol. vol 2, no. No 2, 2011.

[13] A. M. Al-Naimat, S. M. Abdullah and M. A. Khairie, "Critical success factors for e-government implementation in Jordan," in 4th International conference on computing and informatics, Sarawak, 2013.

[14] Mugenda and Mugenda, "research Methods," Nairobi Enon J.C (1998) Educational research, statistics and measurement, 2003.

[15] A. Mohammed, S. Drew and R. AlGhamdi, "Analysis of Citizens' acceptance for E-government services: Applying the UTAUT Model," International conference theory and practice in modern computing and internet Application and research, 2012.

[16] C. L. Kimberlin and A. G. Winterstein, "Validity and reliability of measurement instruments used in research," Am J Health-Syst Pharm, vol. 65, pp. 2276- 2284, 2008.

[17] A. Field, "Reliability Analysis," in Research Methods II, 2006, p. 1.

[18] R. Bentler and D. G. Bonett, "Significance Tests and goodness of Fit in the Analysis of Convariance Structures," pp. pp 37-51, 1988.

[19] D. Gefen and D. Straub, "A practical guide to factorial validity using PLS-Graph: Tutorial and annotated example," The communications of the Associations for Information Systems, vol. 16, no. 5, p. 91-109, 2005.
[20] R. Bagozzi and Y. Yi, "n the Evaluation of Structural Equation Models," Journal of the Academy of Marketing Science, vol. 16, pp. 74-94, 1988.

[21] D. Gichoya, "Factors affecting the success implementation of ICT projects in Government," The Electronic Journal of e-Government, vol. Volume 3, no. Issue 4, 2005.

[22] GOK-EGS, e-government Strategy, 2004, Government press, 2004.

[23] Heeks, Most e-government-for-development Projects fail, how can Risks be reduced? institute for Development Policy and Management, 2003.

[24] R. Heeks, "Information Systems and developing countries: Failure, Success and Improvisations," Electronic Journal of e-government, 2002.

[25] C. G. e. a. Hossan, "Success and failure factors for egovernment projects implementation in Developing Countries: A study on perception of government official of Bangladesh," Electronic Journal of e-government, 2006.

[26] N. Y. Lee, "E-government Application - The academy of ICT essentials for Government leaders," United Nations Asian and Pacific training entre for Information and Communication technology for development, 2009.

[27] S. e. a. Shin, "Implementing e-government in developing countries: Its unique and common success factors," 2006.

[28] A. Al-Naimat, M. Abdallah and F. Ahmad, "Egovernment implementation problems in developing countries," 2nd World Conference on Information Technology (WCIT-2011), vol. Volume 1 (2012), 2012.

[29] R. Heeks, "Information Systems and developing countries: Failure, success and local improvisations," 2002. 